\title{
PROCJENE UČITELJA I UČENIKA O IZVANUČIONIČKOJ NASTAVI U PRIRODI U OSNOVNIM ŠKOLAMA GRADA ZAGREBA
}

\author{
Ivana Sever, Marina Vranić, Krešimir Bošnjak, \\ Ivana Čačić, Martina Protulipac, Mirjana Klepac \\ Zavod za specijalnu proizvodnju bilja, \\ pokušalište Centar za travnjaštvo, \\ Agronomski fakultet Sveučilišta u Zagrebu, \\ Hrvatska \\ severivana1991@gmail.com,mvranic@agr.hr, \\ kbosnjak@agr.hr, icacic@agr.hr, \\ mprotulipac@agr.hr,mklepac@agr.hr
}

Primjeno: 13. 3. 2017.

\begin{abstract}
U radu se prikazuje zastupljenost izvanučioničke nastave u prirodi $s$ naglaskom na osnovne škole grada Zagreba. Ističu se procjene učitelja i učenika o takvom obliku nastave. Istraživanje je provedeno na pokušalištu Sveučilišta u Zagrebu Agronomskog fakulteta Centra za travnjaštvo, anketiranjem učenika i učitelja iz sedam osnovnih škola Grada Zagreba. U prvom dijelu rada prikazuju se rezultati anketa učitelja o preferenciji izvanučioničke nastave u prirodi tijekom jedne školske godine. Osim toga, učitelji procjenjuju koju korist učenici imaju od takve vrste nastave te s kojim se ograničenjima susreću tijekom njene provedbe. U drugom dijelu rada učenici daju svoje mišljenje o izvanučioničkoj nastavi u prirodi. Većina se učenika raduje izvanučioničkoj nastavi, a više od $70 \%$ opredijelilo se za nastavu u prirodi. Učenici nastavu u prirodi doživljavaju kao igru čime se i postiže osnovni cilj izvanučioničke nastave, a to je savladavanje nastavnih cjelina bez opterećenja.
\end{abstract}

Ključne riječi: GradZagreb, izvanučionička nastava u prirodi, osnovna škola, učenici, učitelji

\section{Uvod}

Izvanučioničkom nastavom smatramo svaku nastavu izvan učionice za koju autori koriste različito nazivlje: terenska nastava, nastav- 
na ekskurzija, šetnja, izlet i sl. (Takač, 2013). To je specifičan oblik nastave koji se organizira kako bi se što učinkovitije realizirali oni nastavni sadržaji za koje je potrebno neposredno promatranje i kontakt s izvornom stvarnošću (Husanović-Pejnović, 2011). Primarni izvori najadekvatniji su izvori znanja pa bi izvanučionička nastava prirode i biologije trebala biti sastavnim dijelom nastavnoga rada u školama (Bezić, 1984, 297-302). Temelj školskih ciljeva i programa i jest proučavanje izvorne prirodne i društvene sredine u kojoj čovjek živi, radi i stvara, a s ciljem da se oni koji uče pripreme za bolje snalaženje u susretu s prirodom i drugim ljudima (Bognar i Matijević, 2002). Ona je konkretna, pedagoški učinkovita (De Zan, 1999) i dobar je temelj za daljnji rad u školi (Lešić, 2007). Nastava u prirodi je stvarna nastava, uz mnogo razgovora, opisivanja, pričanja i prepričavanja te ju učenici ne doživljavaju kao opterećenje već je prihvaćaju i provode zainteresirano i s radošću (Jakovljević i Vrgoč, 1999). U današnje vrijeme učenicima izmiče cjelovit pogled na zbivanja u prirodi i društvu pa su stoga prikraćeni u izvornom spoznavanju prirode (Yerkes i Haras, 1997; Borić i Lelas, 2000; Anđić, 2007). Naziv nastavnog predmeta 'Priroda i društvo' govori nam da učenici trebaju upoznati prirodu i društvo, a učionica nije idealno mjesto za spoznavanje okoliša (Jedličko, 2007). Učenje prirode i društva koje se temelji na predavačko-prikazivačkoj nastavi nudi sve manje iskustava »iz prve ruke«, učenici samo sjede, slušaju i gledaju, a učitelj je predavač (Matijević i Radovanović, 2011). Niti jedna učionica, ma kako ona dobro bila opremljena, i niti jedan udžbenik ne mogu zamijeniti odlazak u prirodu (Borić, 2009). Moderna izvanučionička nastava prirode i društva zasniva se na interdisciplinarnosti i multifunkcionalnosti, počiva na timskim i suradničkim oblicima rada te problemskom pristupu što je čini bitnim dijelom odgoja i obrazovanja (Habek, 2015). Znanje treba biti posljedica vlastitog opažanja i razmišljanja, a učenje treba imati karakter pronalaženja i otkrivanja (De Zan, 1999). Nije problem što se do učenika prenose »gotova znanja« ako mu se pritom pruži mogućnost da ta znanja (osobnim istraživanjem) dovede na razinu iskustva (Jelavić, 1998). Ako učenici mogu vježbati na otvorenim prostorima i u zatvorenim prostorijama, a neke prirodne pojave proučavati u učionici ili u prirodi, treba prednost dati otvorenim prostorima i prirodi (Bognar i Matijević, 1993). Svi učenici koji žive i polaze školu u gradovima, nemaju prilike živjeti u prirodi i promatrati prirodne pojave te uočavati prirodne promjene i učiti od prirode (Skok, 2002). Kada djeca na pašnjaku vide konje i krave, pomirišu metvicu, 
čuju klepetanje roda i kreketanje žaba, opipaju kadulju ili okuse divlju kupinu, tada su svim svojim osjetilima doživjeli prirodu. Život u suglasju s prirodom temelj je čovjekova opstanka na Zemlji (Jedličko, 2007). Neke od zadaća izvanučioničke nastave prirode i društva su: povezivanje, primjena i provjera znanja koje je stečeno u učionici (Skok, 2002) s ciljem da stečena znanja i umijeća primjenom različitih razina obrazovnih postignuća postanu trajno vlasništvo učenika (Živanović, 2008). Izvanučioničkom nastavom učenike se potiče na snalaženje u novim okolnostima te ih se upoznaje s novim čimbenicima učenja i nastave, navikava ih se na izvanučioničke izvore znanja i oblike komuniciranja te ih se upoznaje s uvjetima i metodama samostalnog i inovativnog učenja (Skok, 2002). Osim toga, zadaća je izvanučioničke nastave u prirodi da učenike potiče na pravilan odnos prema prirodi i život u skladu s njom, na racionalnije korištenje prirodnih dobara, upoznavanje s kulturnom baštinom (Szczepanski, 2001; Skok, 2002), razvijanje svjesnosti o potencijalnim opasnostima i njihovim posljedicama, odnosno osposobljava ih se za »rješavanje problema« (Skok, 2002).

Većina prednosti izvanučioničke nastave prirode i društva je odgojno-obrazovne naravi (Habek, 2015), preko pozitivnog utjecaja na zdravlje, psihosocijalnog i fizičkog razvoja učenika (Takač, 2013; Habek, 2015), osiguravanja kvalitete znanja (De Zan, 1994; Glasser, 1999; Prnjavorac i Radanović, 2009), vještina i sposobnosti snalaženja u različitim situacijama (De Zan, 1994; Glasser, 1999; Habek, 2015), sve do učenja novih oblika komunikacije (Habek, 2015). Izvanučionička nastava olakšava međupredmetno povezivanje nastavnih sadržaja (De Zan, 1999; Habek, 2015; Boras, 2009; Prnjavorac i Radanović, 2009), nastava se povezuje sa stvarnošću jer se znanja usvajaju dodirom, istraživanjem, otkrivanjem i osobnim iskustvom (Jedličko, 2007), utječe na samostalno promatranje i pridonosi aktivnosti učenika (De Zan, 1999; Habek, 2015), povećava motivaciju i navike kod učenika (Habek, 2015). Takvim radom učenici razvijaju samopouzdanje, kritičko (Stella, 2000; Habek, 2015; Arbunić i Kostović-Vranješ, 2007), divergentno i stvaralačko mišljenje (Jedličko, 2007), međusobno se bolje upoznaju (Habek, 2015), bolje surađuju i skloniji su timskom radu (Bognar i Matijević, 2002) te uspostavljaju bliže odnose s učiteljem (Jedličko, 2007). Učenici se raduju boravku u prirodi, razvija se pravilan odnos prema prirodi (De Zan, 1999; Takač, 2013; Jedličko, 2007) te se ukazuje na važnost zaštite prirode (Stella, 2000). Promatranjem u prirodi djeca shvaćaju povezanost pojava, zakonitosti u prirodi, biljni i životinjski svijet 
u prirodnim uvjetima (Jedličko, 2007), povezuju znanja s prirodom i životom uopće (De Zan, 1999), razumiju međusobne ovisnosti prirode i ljudi, ali između ostalog i proučavanje znanstvenih načela, upoznavanje kulturne baštine i drugo (Stella, 2000). Izvanučioničkom nastavom djeca mogu osjetiti prirodu svim svojim osjetilima u potpunosti te ih potičemo na samostalno promatranje i izučavanje prirode (Boras, 2009; Jedličko, 2007). Prirodna sredina sadrži brojne izvore i poticaje za daljnje spoznaje, budi radoznalost i razvija istraživački duh, što pridonosi razvoju stvaralačkih sposobnosti koje su bitna komponenta u razvoju osobnosti djeteta (Takač, 2013). Ona potiče kreativnost kod učenika (Takač, 2013; Habek, 2015; Boras, 2009) i razvijanje vještina planiranja (Boras, 2009), otvara svijet novih mogućnosti i ideja, obogaćuje novim iskustvima i pomaže u izgradnji svjetonazora (Prnjavorac i Radanović, 2009; Habek, 2015). Rastom učenikovih sposobnosti za samoučenje raste i njegova odgovornost (Young, 2005). Izvanučioničkom nastavom učenici iskustveno uče i dugotrajnije pamte usvojene sadržaje (Bognar i Matijević, 2002; Borić, 2009; Habek, 2015; Lešić, 2007; Jedličko, 2007). Učenici doživljavaju neposrednu stvarnost, uočavaju uzročnoposljedične veze (Stella, 2000; Kanižaj, 2001), usvajaju nova znanja te se na taj način razvija logičko razmišljanje (Kanižaj, 2001). Anđić (2007) spominje neke od poteškoća s kojima se učitelji susreću: organizacijske poteškoće - cjelokupno i konkretno planiranje i pripremanje nastave izvan učionice; školske poteškoće - prilagodba uobičajenog školskog rasporeda; vremenske poteškoće - vrijeme potrebno za planiranje i programiranje ove vrste nastave $\mathrm{i}$ isto tako vremenske prilike; financijske poteškoće; lokacijske poteškoće - nedovoljno poznavanje mjesta koje se posjećuje; sigurnosne poteškoće - podrazumijevaju sigurnost učenika u novoj okolini i svim provedenim aktivnostima; individualne poteškoće - podrazumijevaju nedostatak potrebnih vještina i sposobnosti kako kod učitelja tako i kod učenika za provedbu izvanučioničkog oblika nastave (Anđić, 2007).

\section{Istraživanje}

U istraživanju će se prikazati zastupljenost izvanučioničke nastave u prirodi u osnovnim školama Grada Zagreba. Utvrdit će se preferencija učitelja i učenika prema izvanučioničkoj nastavi u prirodi tijekom jedne školske godine. Osim toga, u rezultatima se planira prikazati i ko- 
rist učenika od takve vrste nastave te s kojim se ograničenjima učitelji susreću tijekom njene provedbe.

\section{Materijali i metode rada}

Istraživanje o procjeni učitelja i učenika osnovnih škola Grada Zagreba prema izvanučioničkoj nastavi u prirodi bilo je provedeno $\mathrm{u}$ sklopu terenske nastave »Upoznajmo domaće životinje« na pokušalištu Sveučilišta u Zagrebu Agronomskog fakulteta, Centra za travnjaštvo na Medvednici. Stočni fond pokušališta sastoji se od 60-ak goveda Charolais i simentalske pasmine raznih kategorija (krave, junice, telad, bikovi), ovaca raznih kategorija (ovce, ovnovi, janjad, šilježice), magaraca, kobila, praščića, kokoši, patki, kunića i riba. Edukativna radionica Centra za travnjaštvo osmišljena je tako da učenici tijekom četiri sata prođu kroz tri etape učenja. Prva etapa podrazumijeva učenje o domaćim životinjama, njihovom izgledu, ponašanju, tjelesnim značajkama, hranidbenim navikama i načinu života na farmi. U drugoj etapi učenicima se $u$ laboratoriju približava znanost $u$ vidu kemijskih pokusa $i$ analiza hrane za hranidbu domaćih životinja. Treća etapa obuhvaća obilazak farme, druženje sa životinjama, hranidbu životinja, učenje postupanja sa životinjama, promatranje okruženja te povezivanje stvarnog iskustva s nastavom u učionici i laboratoriju (usp. Sever et al., 2017).

Istraživanje je bilo provedeno anketiranjem učenika i učitelja iz sedam osnovnih škola Grada Zagreba prilikom posjete pokušalištu, tijekom školske godine 2016./2017. Za statističku analizu podataka korišteni su pokazatelji deskriptivne statistike. Od instrumenata istraživanja korištene su dvije ankete, jedna za učitelje, a druga za učenike. Ankete su bile napisane od strane autora istraživanja. Anketa za učitelje sadržavala je 10 pitanja od kojih se za ovo istraživanje koristilo 5 pitanja, a anketa za učenike sadržavala je 6 pitanja, od kojih se za ovaj rad koristilo 3 pitanja. Preostalih pet pitanja iz ankete učitelja i tri pitanja iz ankete učenika koristilo se u istraživanju Sever et al. (2017). U istraživanje je bilo uključeno 28 učitelja i 528 učenika nižih razreda (2.-4. razreda) osnovnih škola. Anketirani učitelji sudjelovali su dobrovoljno. Učenici su sudjelovali dobrovoljno te uz usmeno odobrenje svojih učitelja.

U anketi je učiteljima postavljeno pitanje o broju odlazaka na izvanučioničku nastavu u prirodi tijekom jedne školske godine. Odgovori su razvrstani u 5 skupina: $0 \mathrm{x}$ - učenike nikada ne vodimo na izvanučioničku nastavu u prirodi; $1-2 \mathrm{x}$ - učenike vodimo jednom do dvaput na 
izvanučioničku nastavu u prirodi; $3-4 \mathrm{x}$ - učenike vodimo tri do četiri puta na izvanučioničku nastavu u prirodi; 5-6 x - učenike vodimo pet do šest puta na izvanučioničku nastavu u prirodi; $>6 \mathrm{x}$, učenike vodimo više od šest puta na izvanučioničku nastavu u prirodi. Na dva pitanja u anketi učitelji su trebali zaokružiti 'DA' ako se slažu s tvrdnjom ili 'NE' ako se ne slažu. Na pitanje o razlozima rijetkog odlaska na izvanučioničku nastavu u prirodi učiteljima je bilo ponuđeno 6 odgovora koje su mogli zaokružiti te nadopisati po želji. Učitelji su imali mogućnost zaokružiti više odgovora za koje su smatrali da opisuju razloge rijetkog odlaska u prirodu. Na pitanje o prednostima i nedostacima izvanučioničke nastave u prirodi učitelji su sami trebali napisati jedan ili više odgovora.

U anketi je učenicima postavljeno pitanje na koje su trebali zaokružiti 'DA' ako se slažu s tvrdnjom ili 'NE' ako se ne slažu. Na pitanje o lokaciji izleta, učenicima su bili ponuđeni odgovori: priroda ili muzej, kazalište i kino. Muzej, kazalište i kino sačinjavali su jednu skupinu odgovora u smislu izvanučioničke nastave koja se ne održava u prirodi. Učenici su trebali zaokružiti jedan odgovor. U anketi je učenicima postavljeno pitanje o razlozima radog odlaska na izvanučioničku nastavu u prirodi. Ponuđeno je četiri odgovora, a učenici su mogli zaokružiti jedan ili više.

\section{Rezultati anketiranja učitelja}

Prvo postavljeno pitanje $u$ anketi glasilo je »Koliko puta tijekom školske godine učenike vodite na izvanučioničku nastavu u prirodi?«

Tablica 1. Broj odlazaka na izvanučioničku nastavu u prirodi u jednoj školskoj godini

\begin{tabular}{|c|c|}
\hline \multicolumn{2}{|c|}{$\begin{array}{c}\text { Koliko puta tijekom školske godine učenike vodite na } \\
\text { izvanučioničku nastavu u prirodi? }\end{array}$} \\
\hline Broj odlazaka u prirodu & \% učitelja \\
\hline $0 \mathrm{x}$ & 0 \\
\hline $1-2 \mathrm{x}$ & 39,28 \\
\hline $3-4 \mathrm{x}$ & 35,71 \\
\hline $5-6 \mathrm{x}$ & 17,85 \\
\hline$>6 \mathrm{x}$ & 7,14 \\
\hline
\end{tabular}


Iz Tablice 1 vidljivo je da je najveći broj učitelja odgovorio da s učenicima ide jednom do dvaput na izvanučioničku nastavu u prirodi tijekom jedne školske godine, a odmah iza toga slijedi broj od tri do četiri odlazaka. S obzirom da temelj školskih ciljeva i programa i jest proučavanje izvorne prirodne i društvene sredine u kojoj čovjek živi, radi i stvara (Bognar i Matijević, 2002), a u današnje vrijeme učenicima izmiče cjelovit pogled na zbivanja u prirodi i društvu pa su stoga prikraćeni u izvornom spoznavanju prirode (Yerkes i Haras, 1997; Borić i Lelas, 2000; Anđić, 2007), može se zaključiti da je toliki broj odlazaka u prirodu učenicima nedovoljan.

Prema Nastavnom planu i programu za osnovne škole (2006) nema propisanog broja sati za izvođenje nastave u prirodi, već su sve informacije napisane $u$ vidu preporuka i smjernica za struku (npr. škola u prirodi na Medvednici nije obvezna nego se preporučuje; osobna komunikacija). Prema tome, učenikov doživljaj prirode ovisi isključivo o školi, odnosno volji učitelja za takvom vrstom nastave. Dok je mnogim učenicima nastava u prirodi nažalost uskraćena, drugima se ona podrazumijeva kao sastavni dio školske godine. Stoga je potrebno raditi na tome da se u školama takva vrsta nastave izjednači, odnosno propiše obvezan broj sati koji učitelji moraju provesti s učenicima u prirodi.

Drugo postavljeno pitanje bilo je »Smatrate li da bi s učenicima trebalo više ići na izvanučioničku nastavu u prirodi?«

Tablica 2. Procjena učitelja o broju sati provedenih na izvanučioničkoj nastavi u prirodi

\begin{tabular}{|c|c|}
\hline \multicolumn{2}{|c|}{$\begin{array}{c}\text { Smatrate li da bi se trebalo } \mathbf{s} \text { učenicima više ići na } \\
\text { izvanučioničku nastavu u prirodi? }\end{array}$} \\
\hline Odgovor & \% \\
\hline $\mathrm{Da}$ & 92,85 \\
\hline $\mathrm{Ne}$ & 7,15 \\
\hline
\end{tabular}

Iz Tablice 2 vidljivo je da 92,85 \% učitelja smatra da bi se trebalo s učenicima više ići na izvanučioničku nastavu u prirodi, a prema rezultatima Lukša et al. (2014), 87 \% učitelja smatra da bi ovakav oblik nastave trebao biti češće zastupljen u školama. Osim toga, Lukša et al. (2014) dolaze do zaključka da unatoč iskazanom zadovoljstvu učitelja terenskom nastavom i mišljenjem kako je ona efikasniji i bolji način rada za spoznavanje nekih sadržaja nego nastava u učionici, učitelji ne 
organiziraju često terensku nastavu pa i učenici smatraju da je nema dovoljno. Nadalje, rezultati iz Tablice 2 potvrđuju rezultate Anđić (2007) i Borić et al. (2010) koji su zaključili da učitelji razredne nastave učenje i poučavanje na otvorenim prostorima i okolišu smatraju značajnim dijelom svoje prakse rada u školama i rado izvode učenike na otvorene prostore, te da su učitelji visoko motivirani za provođenje izvanučioničke nastave i procjenjuju se vrlo kompetentnima za njeno provođenje.

Treće pitanje postavljeno učiteljima bilo je »Koji je razlog rijetkog odlaska na izvanučioničku nastavu u prirodi?«

Tablica 3. Razlozi rijetkog odlaska na izvanučioničku nastavu u prirodi

\begin{tabular}{|l|c|}
\hline \multicolumn{2}{|c|}{ Koji je razlog rijetkog odlaska na izvanučioničku nastavu u prirodi? } \\
\hline \multicolumn{1}{|c|}{ Odgovor } & \% učitelja \\
\hline Financijske mogućnosti roditelja & 78,57 \\
\hline Nemogućnost dogovora s ostalim učiteljima & 0 \\
\hline Nedovoljna podrška škole & 3,57 \\
\hline Previše posla oko organizacije & 25 \\
\hline Premala ponuda programa & 17,85 \\
\hline Drugo: nedostatak vremena; nediscipliniranost učenika & 10,71 \\
\hline
\end{tabular}

Navedeni rezultati podudaraju se $\mathrm{s}$ istraživanjem Lukša et al. (2014) koji navode da su glavni razlozi financijske mogućnosti roditelja, nedovoljna podrška škole, problem prijevoza. Od ostalog, Lukša et al. (2014) navode previše posla i odgovornosti, potom da učenici ne pokazuju interes za takav oblik nastave, te stav da učenici ne nauče dovoljno kroz takav oblik nastave.

Četvrto pitanje postavljeno učiteljima glasilo je »Smatrate li da izvanučioničkom nastavom u prirodi učenici više nauče, motiviraniji su za rad i steknu trajnija znanja?«

Tablica 4. Procjena učitelja o utjecaju izvanučioničke nastave u prirodi na učenike

\begin{tabular}{|c|c|}
\hline $\begin{array}{c}\text { Smatrate li da izvanučioničkom nastavom u prirodi učenici više nauče, } \\
\text { motiviraniji su za rad i steknu trajnija znanja? }\end{array}$ \\
\hline Potvrdan odgovor & \% učitelja \\
\hline 28 & 100 \\
\hline
\end{tabular}


Iz Tablice 4 vidljivo je da $100 \%$ učitelja smatra da izvanučioničkom nastavom u prirodi učenici više nauče, motiviraniji su za rad i steknu trajnija znanja. Lukša et al. (2014) dolaze do rezultata u kojima $3 \%$ učitelja smatra da učenici ne nauče više takvim oblikom nastave. Nasuprot tome, učenici smatraju da takvim oblikom rada izvan učionice nauče puno više.

Peto pitanje postavljeno učiteljima bilo je »Koje su prednosti, a koji nedostaci izvanučioničke nastave u prirodi?«

Tablica 5. Procjena učitelja o prednostima i nedostacima izvanučioničke nastave u prirodi

\begin{tabular}{|l|c|l|c|}
\hline \multicolumn{4}{|c|}{$\begin{array}{c}\text { Mišljenja nastavnika o prednostima i ograničenjima } \\
\text { izvanučioničke nastave u prirodi }\end{array}$} \\
\hline \multicolumn{1}{|c|}{ Prednosti } & \% učitelja & \multicolumn{1}{c|}{ Nedostaci } & \% učitelja \\
\hline $\begin{array}{l}\text { Djeca svim osjetilima } \\
\text { doživljavaju prirodu }\end{array}$ & 57,14 & Nema nedostataka & 64,28 \\
\hline $\begin{array}{l}\text { Djeca bolje pamte ono } \\
\text { što uživo vide i čuju }\end{array}$ & 46,42 & Financijski problemi & 14,28 \\
\hline $\begin{array}{l}\text { Boravak na svježem zraku } \\
\text { i tjelesna aktivnost }\end{array}$ & 28,57 & $\begin{array}{l}\text { Problem organizacije i } \\
\text { nepoznavanje prostora } \\
\text { u koji se ide }\end{array}$ & 14,28 \\
\hline $\begin{array}{l}\text { Aktivnije sudjelovanje } \\
\text { u nastavi }\end{array}$ & 3,57 & $\begin{array}{l}\text { Velika odgovornost nastavnika } \\
\text { i nediscipliniranost učenika }\end{array}$ & 10,71 \\
\hline Slobodnije izražavanje & 3,57 & $\begin{array}{l}\text { Ovisnost o vremenskim } \\
\text { prilikama }\end{array}$ & 3,57 \\
\hline
\end{tabular}

Borić et al. (2010) utvrdili su da se učitelji slažu oko nedostataka da je ovakva vrsta nastave zahtjevnija za planiranje, pripremanje i realizaciju. Lukša et al. (2014) istražili su stavove učitelja o prednostima i nedostacima izvanučioničke nastave biologije. Prema tom istraživanju, učitelji navode razvijanje timskog rada i bolje upoznavanje učenika kao najveću prednost, ističu dulje pamćenje sadržaja, zabavnije učenje za učenike i suradnju s profesorima izvan škole. Kao glavni nedostatak ističu financijske mogućnosti roditelja, zatim visoke cijene smještaja, previše posla oko organizacije takve vrste nastave, neodgovornost nekih učenika i nezainteresiranost roditelja, te da učenici nisu zainteresirani za ovakav oblik nastave. 


\section{Rezultati anketiranja učenika}

U anketi za učenike prvo postavljeno pitanje bilo je »Volite li kada se u vašoj školi organizira izlet u prirodu? «

Tablica 6. Postotak učenika koji rado odlaze na izvanučioničku nastavu u prirodi

\begin{tabular}{|l|c|}
\hline \multicolumn{2}{|c|}{$\begin{array}{c}\text { Volite li kada se u vašoj školi organizira izvanučionička } \\
\text { nastava u prirodi? }\end{array}$} \\
\hline \multicolumn{1}{|c|}{ Odgovor } & $\mathbf{\%}$ \\
\hline $\mathrm{Da}$ & 91,85 \\
\hline $\mathrm{Ne}$ & 3,59 \\
\hline $\mathrm{Nisu}$ izrazili mišljenje & 4,54 \\
\hline
\end{tabular}

Prema dobivenim rezultatima, 91,85\% učenika rado ide na izvanučioničku nastavu u prirodu. Dobiveni rezultati potvrđuju i rezultate anketa Lukša et al. (2014) koji govore da učenici rado prihvaćaju školu u prirodi kao oblik učenja novih sadržaja te smatraju da takvim oblikom rada nauče puno više. Osim toga, Jedličko (2007) utvrđuje da djeca vole učiti neposrednim iskustvom u prirodnom okruženju. Boravak izvan učionice više ih motivira i angažira u spoznavanju nastavnih sadržaja, a djeci se najviše sviđa istraživačka nastava. Osim toga, roditelji podržavaju školu u prirodi i smatraju da djeca tako brže, lakše i bez opterećenja uče. Arambašić (2013) utvrđuje da učenici visoko procjenjuju motivaciju za provođenje nastave izvan učionice te vide više prednosti nego mana istraživačke izvanučioničke nastave Prirode i društva. Zaključuje da su učenici motivirani za istraživačku izvanučioničku nastavu Prirode i društva te da se i dalje trebaju provoditi ovakvi oblici nastave. Analizom evaluacijskih listića Arambašić (2013) uočava da se većini učenika najviše svidjela ovakva organizacija nastave Prirode i društva.

Drugo pitanje postavljeno učenicima bilo je gdje najviše vole ići na izvanučioničku nastavu.

Tablica 7. Postotak učenika koji se opredjeljuje za izvanučioničku nastavu u prirodi, odnosno posjet kinu, kazalištu ili muzeju

\begin{tabular}{|l|c|}
\hline Više volim ići na izvanučioničku nastavu u: & $\mathbf{\%}$ \\
\hline Prirodu & 73,86 \\
\hline Kino, kazalište, muzej & 14,77 \\
\hline Nisu izrazili mišljenje & 11,36 \\
\hline
\end{tabular}


Prema dobivenim rezultatma, 73,86 \% učenika više se raduje izletima u prirodu. Učenici koji žive i polaze školu u gradovima nemaju prilike živjeti u prirodi i promatrati prirodne pojave te uočavati prirodne promjene, učiti od prirode (Skok, 2002). Aračić (2008) je utvrdila da učenici vole istraživačku nastavu, daju joj prednost i žele da je više zastupljena u nastavi.

Treće postavljeno pitanje $u$ anketi učenika istražilo je zbog čega učenici vole izvanučioničku nastavu u prirodi.

Tablica 8. Razlozi radog odlaska učenika na izvanučioničku nastavu u prirodi

\begin{tabular}{|l|c|}
\hline \multicolumn{2}{|c|}{ Izvanučioničku nastavu u prirodi volim zbog: } \\
\hline \multicolumn{1}{|c|}{ Odgovor } & \% učenika \\
\hline Dobre zabave & 57,76 \\
\hline Naučim puno više na izletu nego u učionici & 39,96 \\
\hline Izostanka iz škole & 15,53 \\
\hline Upoznavanja novih mjesta i sadržaja & 50,75 \\
\hline Nisu izrazili mišljenje & 7,76 \\
\hline
\end{tabular}

Rezultati iz Tablice 8 potvrđuju rezultate Lukša et al. (2014) prema kojima je $50 \%$ učenika odgovorilo da ih najviše veseli provod i dobra zabava, 15 \% izostanak iz škole, $15 \%$ učenje uz zabavu, $11 \%$ upoznavanje novih mjesta i sadržaja, $4 \%$ ih se raduje tome što nema ocjena i $3 \%$ mogućnost timskog rada. Rezultati prikazuju da učenici izvanučioničku nastavu u prirodi doživljavaju kao dobru zabavu.

\section{Zaključak}

Iz provedenog istraživanja može se zaključiti da bi izvanučioničku nastavu u prirodi u osnovnim školama Grada Zagreba trebalo provoditi češće. Prednosti takve vrste nastave su brojne, od tjelesne aktivnosti i boravka u prirodi, do aktivnijeg sudjelovanja učenika u nastavi. Velika odgovornost uspješne izvanučioničke nastave u prirodi leži na učiteljima te ovakav oblik nastave zahtjeva veću pripremu od klasičnog učioničkog sata. Rezultati pokazuju da unatoč mišljenju učitelja kako nedovoljno odlaze na izvanučioničku nastavu u prirodi i dalje postoje problemi na koje učitelji ne mogu utjecati, a ponajviše se odnose na 
financijska ograničenja. Rezultati ankete učenika pokazuju da učenici više preferiraju izvanučioničku nastavu u prirodi nego izvanučioničku nastavu koja se ne održava u prirodi. Osim toga, izvanučioničku nastavu u prirodi doživljavaju kao igru čime se i postiže osnovni cilj izvanučioničke nastave, a to je savladavanje nastavnih cjelina bez opterećenja. Ovakva nastava, osim što rasterećuje učenike, omogućuje ostvarivanje iskustvenog učenja koje vodi do trajnog znanja jer će u kontaktu s prirodom učenici naučene sadržaje lakše i bolje zapamtiti.

\section{Literatura}

Anđić, Dunja (2007), »Učenje i poučavanje prirode i društva na otvorenim prostorima«, Metodički obzori, 2(1), str. 7-23.

Aračić, Nikolina (2008), Praktični rad u nastavi Prirode i društva. Diplomski rad. Učiteljski fakultet, Sveučilište J. J. Strossmayera u Osijeku, Dislocirani studij u Slavonskom Brodu.

Arambašić, Vanesa (2013), Istraživačka izvanučionička nastava Prirode i društtva u 4. razredu. Završni rad. Učiteljski fakultet, Sveučilište J. J. Strossmayera u Osijeku.

Arbunić, Antun; Kostović-Vranješ, Vesna (2007), »Nastava i izvori znanja«, Odgojne znanosti, 9(2), str. 97-111.

Bezić, Krešimir (1984), Metodika prirode i društva, Zagreb: Školska knjiga.

Bognar, Ladislav; Matijević, Milan (1993), Didaktika, Zagreb: Školska knjiga.

Bognar, Ladislav; Matijević, Milan (2002), Didaktika, Zagreb: Školska knjiga.

Boras, Mirjana (2009), »Suvremeni pristupi nastavi prirode i društva«, Život i škola, 21(57), str. 40-49.

Borić, Edita; Labak, Irena (2006), »Istraživačka nastava kao standard suvremene škole«, u: Besendrfer, Višnja; Klobučar, I. V. Goran (ur.), 9. Hrvatski biološki kongres, Rovinj: Hrvatsko biološko društvo 1885, 2006, str. 420-421.

Borić, Edita (2009), Istraživačka nastava prirode i društva. Dostupno na: https:// www.ffst.unist.hr/_download/repository/doc._dr._sc._edita_boriC_istraZivaCka_nastava_prirode_i_druStva_(prirucnik_za_nastavu).pdf [23. 1.2017$]$

Borić, Edita; Lelas, Zdenka (2000), »Efikasnost učenja biocenoza livada različitim oblicima rada na terenu«, Život $i$ škola, 3, str. 103-110.

Borić, Edita; Škugor, Alma; Perković, Ivana (2010), »Samoprocjena učitelja o izvanučioničkoj istraživačkoj nastavi prirode i društva«, Odgojne znanosti, 12(2), str. 361-373.

De Zan, Ivan (1994), Istraživačka nastava biologije, Zagreb: Školske novine. 
De Zan, Ivan (1999), Metodika nastave prirode i društva, Zagreb: Školska knjiga. Glasser, William (1999), Učitelj u kvalitetnoj školi, Zagreb: Educa.

Grinfelder, Biljana (2010), Pokus u nastavi prirode i društva. Završni rad. Učiteljski fakultet, Sveučilište J. J. Strossmayera u Osijeku.

Habek, Kristina (2015), Mišljenje učitelja o izvanučioničkoj nastavi prirode i društva. Diplomski rad. Odsjek za učiteljske studije, Učiteljski fakultet, Sveučilište u Zagrebu.

Husanović-Pejnović, Dragica (2011), Održivi razvoj i izvanučionička nastava u zavičaju, Zagreb: Školska knjiga.

Jakovljević, Nada; Vrgoč, Danica (1999), Škola u prirodi: priručnik za učitelje, Zagreb: Hrvatsko pedagoško-književni zbor.

Jedličko, Jasna (2007), Nastavne strategije i socijalni oblici rada u izvanučioničkoj nastavi prirode $i$ društva. Magistarski rad. Odsjek za učiteljske studije, Učiteljski fakultet, Sveučilište u Zagrebu.

Jelavić, Filip (1998), Didaktika, Jastrebarsko: Naklada Slap.

Kanižaj, Jagoda (2001), Škola u prirodi, Varaždin: Vall 042.

Lešić, Nikolina (2007), Izvanučionička nastava u prirodi i društvu. Diplomski rad. Odsjek za učiteljske studije, Učiteljski fakultet, Sveučilište u Zagrebu.

Lukša, Žaklin; Žamarija, Maja; Dragić Runjak, Tea; Sinković, Nevenka (2014), »Terenska nastava prirode i biologije u osnovnoj školi«, Educatio biologiae, 1(1), str. 69-79.

Matijević, Milan; Radovanović, Diana (2011), Nastava usmjerena na učenika, Zagreb: Školske novine.

Nastavni plan i program za osnovnu školu (2006), Zagreb: Ministarstvo znanosti, obrazovanja i športa. Dostupno na: http://www.azoo.hr/images/AZOO/Ravnatelji/RM/Nastavni_plan_i_program_za_osnovnu_skolu_-_MZOS_2006_.pdf [29. 9. 2017.]

Prnjavorac, Jasna; Radanović, Ines (2009), »Uloga školskog dvorišta u nastavi prirode i biologije«, u: Besendorfer, Višnja; Kopjar, Nevenka; Vidaković-Cifrek, Željka; Tkalec, Mirta; Bauer, Nataša; Lukša, Žaklin (ur.), Zbornik sažetaka 10. Hrvatskog biološkog kongresa, Zagreb: Hrvatsko biološko društvo 1885, 2009, str. 341-342.

Sever, Ivana; Vranić, Marina; Bošnjak Krešimir; Čačić, Ivana; Protulipac, Martina; Klepac, Mirjana (2017), »Poznavanje domaćih životinja kod učenika nižih razreda osnovnih škola Grada Zagreba«, Agronomski glasnik, 1-2, str. 25-40.

Skok, Pavao (2002), Izvanučionička nastava, Zagreb: Pedagoški servis.

Stella, Ivo (2000), Priprema i provedba školskih izleta, ekskurzija i putovanja, Zagreb: Mladost. 
Szczepanski, Anders (2001), »What is outdoor education?«, u: Bowles, S., Higgins, P., Humberstone, B. (ur.), 4th Eurocongress of European Institute for Outdoor Adventure Education and Experiential Learning: Other Ways of Learning, Margburg: European Institute for Outdoor Adventure Education and Experiential Learning, str. 17-24.

Takač, Monika (2013), Izvanučionička nastava - škola u prirodi. Diplomski rad. Odsjek za učiteljske studije, Učiteljski fakultet, Sveučilište u Zagrebu.

Yerkes, Robert; Haras, Kathy (1997), »Outdoor education and environmental responsibility«, Eric Digest: ERIC Clearinghouse on Rural Education and Small Schools.

Young, Richard M. (2005), »The motivational effects of the classroom environment in facilitating, self-regulated learning«, Journal of Marketing Education, 27(1), str. 25-40.

Živanović, Slobodan B. (2008), »Primjena diferenciranih zadataka u nastavi biologije «, Metodički ogledi, 15(1), str. 83-97.

\title{
TEACHER AND PUPIL EVALUATION OF OUTDOOR EDUCATION IN ZAGREB'S ELEMENTARY SCHOOLS
}

\author{
Sever Ivana, Vranić Marina, Bošnjak Krešimir, \\ Čačić Ivana, Protulipac Martina, Klepac Mirjana
}

This research shows the presence of outdoor education, with an emphasis on primary schools in Zagreb, Croatia. Teacher and pupil evaluations of this form of teaching are examined. This research was conducted at the University of Zagreb's Graduate School of Agronomy at the Grasslands Centre through a survey of elementary school pupils and teachers from Zagreb. The first part of the research presents the results of the teacher survey on their preference for outdoor education during one school year. In addition, teachers evaluated the benefits pupils gain from this type of teaching and which limitations they encounter during its implementation. In the second part of the research, students provide their opinion about outdoor education. Most of the students are delighted with outdoor education, and over $70 \%$ opt for outdoor education. Pupils perceive outdoor education as play, thus achieving the basic goal of outdoor education, which is to master teaching units without any burdens.

Key words: elementary school, outdoor education, students, teachers, Zagreb 